\section{Leaching for iron removal from low-grade bauxite ore to access refractory instruction}

Rudarsko-geološko-naftni zbornik

(The Mining-Geology-Petroleum Engineering Bulletin) UDC: $622: 669$

DOI: 10.17794/rgn.2022.1.6

Original scientific paper

\author{
Zahra Jalili'; Ataallah Bahrami'; Masoud Ghadri²; Behzad Nemati Akhgar'; Fatemeh Kazemi \\ ${ }^{1}$ Department of Mining Engineering, Faculty of Engineering, Urmia University-Iran. \\ ${ }^{2}$ Ghezel Gheye Bauxite Mine engineer, West Azerbaijan province, Shahin-dezh city-Iran. \\ ${ }^{3}$ PhD student of mineral processing, Faculty of Engineering, University of Kashan-Iran.
}

\begin{abstract}
Iron-bearing minerals are the most important interfering compounds that are found with bauxite reserves. The element iron has adverse effects on bauxite applications, including the use of bauxite in refractory soils. The purpose of this research is to investigate the possibility of iron removal from low-grade bauxite ores to utilize them in refractory industries. For achieving this purpose, iron removal tests were performed on bauxite samples with an alumina to silica modulus of o.73. After determining the appropriate iron removal method among the magnetic separation, calcination, and leaching (with $\mathrm{H}_{2} \mathrm{SO}_{4}$ and $\mathrm{HCl}$ ) processes, optimal separation conditions were determined by tests that were designed using the Taguchi method. According to leaching results, using $\mathrm{HCl}$ for raw feed (un-calcined) provided the best result for iron removal. During this test, $\mathrm{Fe}_{2} \mathrm{O}_{3}$ grade decreased from $5.14 \%$ to $0.08 \%$, and the alumina to silica modulus increased to 0.75. Calcination of the concentrate obtained from this test has led to favorable results in reducing the $\mathrm{Fe}_{2} \mathrm{O}_{3}$ grade $(0.04 \%)$ and increasing the $\mathrm{Al}_{2} \mathrm{O}_{3}$ grade. Afterwards, in tests designed by the Taguchi method, the effect of parameters such as time, process temperature, $\mathrm{HCl}$ concentration, and feed grain size on iron removal from bauxite by $\mathrm{HCl}$ leaching processes are discussed. According to the results, the best efficiency of iron removal for a feed grain size of $250 \mu \mathrm{m}$ is achieved in the following conditions: $30 \% \mathrm{HCl}$, process temperature of $25{ }^{\circ} \mathrm{C}$, and process time of 120 minutes. In this case, iron removal efficiency and $\mathrm{Fe}_{2} \mathrm{O}_{3}$ grade in process concentrate are $92.78 \%$ and $0.56 \%$, respectively.
\end{abstract}

\title{
Keywords:
}

bauxite; iron removal; leaching; Taguchi; refractory

\section{Introduction}

Bauxite ores are materials left over from the degradation and erosion of primary rocks such as granite, basalt, and nepheline syenite, or clay minerals. Bauxite reserves contain high amounts of aluminum and are one of the most important aluminum ores (Donaldson and Raahauge, 2017). So far, more than 100 minerals have been identified for bauxites, of which only a few, including gibbsite $\mathrm{Al}(\mathrm{OH})_{3}$, boehmite $(\gamma-\mathrm{AlO}(\mathrm{OH}))$, and diaspore $(\alpha-\mathrm{AlO}(\mathrm{OH}))$ are important reserves of aluminum (Pereira et al., 2019). More than 95\% of the world's bauxite reserves are used in the alumina industry and metal production; the remaining $5 \%$ is used in abrasive, refractory, cement, chemical, and metal industries. In each case, depending on the type of application of bauxite, the standard and its chemical composition are varied. The standard chemical analysis for bauxites used in various industries is summarized in Table 1. For example, bauxites used in the metal industry contain a high amount

Corresponding author: Ataallah Bahrami

a.bahrami@urmia.ac.ir of aluminum and low amount of iron, silica, and titanium. In bauxites used in the refractory industry, the amount of aluminum is high, iron and silica are low, and the amount of alkalis is very low. Typically bauxites used in the refractory industry are diasporas containing high aluminum and silica and low Al / Si ratios. High aluminum refractories (HAR) have wide applications in high-temperature industries such as ceramics, glass, bricks, and refractory cement (Roskill, 2016).

Refractories are heat-resistant materials, which are exposed to different degrees of mechanical and thermal stress, corrosion-erosion of solids, liquids and gases, gas diffusion, and mechanical wear (Schacht, 2004). Compared to the aluminum industry, the scale of the refractory industry is smaller. Hence, due to the development of the aluminum industry and its applications, there is a severe shortage of bauxite reserves containing high aluminum for use in refractory industries. Therefore, refractory producers have focused on medium to lowgrade bauxite reserves and their efficiency and purification methods. In this regard and in recent years, more precise processes and technologies, as well as various preprocessing methods, such as calcination, have been 
Table 1: Bauxite standard for its use in various industries

\begin{tabular}{|l|l|l|l|l|l|}
\hline Element & $\begin{array}{l}\text { Meta } \\
\text { industry }\end{array}$ & Cement & $\begin{array}{l}\text { Chemi- } \\
\text { cal }\end{array}$ & $\begin{array}{l}\text { Refrac- } \\
\text { tories }\end{array}$ & Abrasive \\
\hline $\mathrm{Al}_{2} \mathrm{O}_{3} \%$ & $55-50$ & $55-45$ & $>55$ & $>84.50$ & $88-80$ \\
\hline $\mathrm{SiO}_{2} \%$ & $15-0$ & $<6$ & $18-5$ & $<7.50$ & $8-4$ \\
\hline $\mathrm{Fe}_{2} \mathrm{O}_{3} \%$ & $30-5$ & $30-20$ & $<2$ & $<2.50$ & $5-2$ \\
\hline $\mathrm{TiO}_{2} \%$ & $6-0$ & 3 & $6-0$ & $<4$ & $5-2$ \\
\hline
\end{tabular}

used to enrich low-grade bauxite reserves. Following these advances and changes in technology, the $\mathrm{Al} / \mathrm{Si}$ ratio required by downstream processes has been reduced by about 4-5 times, and large quantities of low to medium-grade bauxites have been economically and practically justified (Deng et al., 2017). On the other hand, due to the abundance of compounds including $\mathrm{Fe}_{2} \mathrm{O}_{3}, \mathrm{Al}_{2} \mathrm{O}_{3}, \mathrm{TiO}_{2}$, and $\mathrm{Na}_{2} \mathrm{O}$, as well as the presence of rare earth elements such as scandium, gallium, uranium, and thorium, bauxite reserves are considered as a secondary source of these elements from an economically appropriate point of view. Hence, in recent years, various methods of pyrometallurgy and hydrometallurgy have been used to recover these compounds.

Kaolinite, hematite, magnetite, goethite, siderite, and quartz are the most common minerals associated with bauxite reserves. In addition to the above, there may be amounts of rutile, anatase, and zircon minerals. Due to the diversity of minerals associated with bauxite reserves, the melting temperature of these ores will increase to $1800^{\circ} \mathrm{C}$ and even more (Cardarelli, 2018). These compounds, together with bauxite reserves, lead to the formation of alkaline compounds and crystalline phases during calcination. These phases, in addition to a reduction in temperature and forming the glass phase, reduce the corrosion resistance, facilitate the formation of slag ash, and increase the depositional mechanisms. $\mathrm{Fe}_{2} \mathrm{O}_{3}, \mathrm{TiO}_{2}$, and $\mathrm{R}_{2} \mathrm{O}$ ( $\mathrm{R}$ in this formula is $\mathrm{Na}$ or $\mathrm{K}$ ) are among the most important compounds in bauxite reserves that have an improper impact on the performance of bauxite in refractory industries, and must be reduced or eliminated during processing. These impurities prevent the formation of mullite and corundum phases. According to studies, these impurities are in the form of an amorphous phase with micro and liquid phase structures, which increase the volume of the material under high temperatures. As a result of this function, the structure of the material is destroyed and its service life is reduced. In general, these phases increase the melting point of the product to $1850^{\circ} \mathrm{C}$, create high thermal shock, resistance against viscosity, and reduce the mechanical resistance of refractories. It also leads to behaviors such as reduced mechanical strength and thermal instability (Schacht, 2004).

There are several ways to de-ironize bauxite; in this regard, various and extensive research studies have been done. For example, flotation has been used for silica removal, desulfurization, and synthesis of chemicals to prepare bauxite for alumina industries (Zhong, 2009).
However, few studies have been conducted on bauxite processing from standpoint of the application of lowgrade bauxite in the refractory industry. In the study done by Papassiopi et al., (2010), to remove iron from bauxite they used bacteria during the leaching process. In this process, $95 \%$ of amorphous ferrohydrite is dissolved, while the removal efficiency of goethite and hematite was less than $9 \%$ and $1.20 \%$, respectively. Also, in the field of iron removal of low-grade diaspora bauxites, the use of the thermochemical method and heat-induced changes in minerals found in bauxite and various chemical reactions during this method have been studied. The overall result indicated that the iron content in the residual solid decreased from $27.20 \%$ to $1.59 \%$ (Stjernberg et al., 2012). A study has been performed on the dissolution of iron (high amount of Fe) in bauxites in sulfuric acid. The results of this study indicate that the amount of iron leached using acid with a concentration of $20 \%$, and the process temperature of $100^{\circ} \mathrm{C}$ is 98.68\% (Zhao et al., 2012). Hu et al., (2016) investigated the possibility of performing direct reduction processes on ferric bauxite. For this purpose, during the process (in which coal was used as a reduction agent), the produced iron powder has been removed from the solution using magnetic devices. In the study done by Rai et al., (2019) advanced physical recovery techniques, such as multistage magnetic separation, use of carbon-containing wastes as reducing agents and separation using hydro cyclone have been discussed. In the study done by Deng et al., (2019) the ideal conditions for the leaching process was determined through response surface methodology (RSM) to be an $\mathrm{H}_{3} \mathrm{PO}_{4}$ concentration of $1.2 \mathrm{~mol} / \mathrm{L}, \mathrm{L} / \mathrm{S}$ ratio of $11 \mathrm{~mL} / \mathrm{g}$ and a leaching temperature of $40^{\circ} \mathrm{C}$. An advanced roasting technique for removing iron from high-iron bauxite, based on static pre-roasting in air and suspension roasting by hydrogen under fluidized conditions followed by magnetic separation was developed (Yuan et al., 2020). Currently, several Iranian bauxite reserves are facing the challenge of high levels of impurities, including $\mathrm{Fe}_{2} \mathrm{O}_{3}$, $\mathrm{TiO}_{2}$, and $\mathrm{R}_{2} \mathrm{O}$. On the other hand, the low degree of liberation of the minerals containing the mentioned compounds and the way they interact with other minerals in the reserve has caused many complications in their comminution and separation methods. In this research, due to the existence of potential sources of bauxite in the West Azerbaijan province, including Ghezel Ghiyeh bauxite deposit (Shahindej city), they have been processed for use in refractory soil. In this regard, an attempt has been made to remove the iron in the ore by calcination and leaching methods and to bring its grade to the permissible level used in the refractory industry.

\section{Methods and Materials}

In this section, first, explanations and information about the case study are provided. Then, the test methods are described. 
Table 2: Results of XRF analysis of the studied bauxite

\begin{tabular}{|l|l|l|l|l|l|l|l|l|l|l|l|}
\hline Composition & $\mathbf{A l}_{2} \mathbf{O}_{3}$ & $\mathbf{F e}_{2} \mathbf{O}_{3}$ & $\mathbf{S i O}_{2}$ & $\mathbf{T i O}_{2}$ & $\mathbf{K}_{2} \mathbf{O}$ & $\mathbf{B a O}$ & $\mathbf{C a O}$ & $\mathbf{M g O}$ & $\mathbf{M n O}$ & $\mathbf{N a}_{2} \mathbf{O}$ & $\mathbf{L O I}$ \\
\hline Amount (\%) & 32.81 & 5.14 & 44.82 & 1.15 & 0.51 & 0.47 & 0.46 & 0.49 & $<0.1$ & 0.39 & 13.75 \\
\hline
\end{tabular}

Table 3: Results of ICP-MS analysis of the studied bauxite (elements with a value less than $0.5 \mathrm{ppm}$ are not listed)

\begin{tabular}{|l|l|l|l|l|l|l|l|l|l|l|}
\hline Element & As & B & Ba & Ca & Co & Cr & Cu & Ga & V & K \\
\hline Amount $(\mathrm{ppm})$ & 22.27 & 72.19 & 29.96 & 1845.69 & 4.05 & 82.73 & 20.24 & 20.24 & 79.45 & 962.47 \\
\hline Element & $\mathrm{La}$ & $\mathrm{Li}$ & $\mathrm{Mg}$ & $\mathrm{Mn}$ & $\mathrm{Mo}$ & $\mathrm{Na}$ & $\mathrm{Nb}$ & $\mathrm{Nd}$ & $\mathrm{W}$ & $\mathrm{Ni}$ \\
\hline Amount $(\mathrm{ppm})$ & 5.44 & 252.27 & 535.69 & 38.37 & 10.42 & 2668.22 & 59.76 & 3.98 & 3.34 & 37.32 \\
\hline Element & $\mathrm{P}$ & $\mathrm{Pb}$ & $\mathrm{Zr}$ & $\mathrm{Sb}$ & $\mathrm{Sc}$ & $\mathrm{Sn}$ & $\mathrm{Sr}$ & $\mathrm{Th}$ & $\mathrm{Zn}$ & $\mathrm{Ti}$ \\
\hline Amount $(\mathrm{ppm})$ & 54.24 & 53.57 & 123.19 & 22.07 & 8.84 & 8.04 & 49.01 & 3.28 & 82.56 & 6989.68 \\
\hline
\end{tabular}

\subsection{Introduction of studied low-grade bauxite ores}

Ghezel Ghiyeh bauxite mine is located in the northwest of the Iran (Shahindej city - West Azerbaijan province). The mine has a measured resource of 185,000 tons, and an indicated resource of 370,000 tons. The annual extraction rate is equal to 3,000 tons, which is done by an excavator with a pneumatic hammer and loader. Bauxite deposits located in northwestern Iran are mainly related to the Permian and Permian-Triassic geological periods. During the Permian period, sea regression and advancement led to clastic and carbonate sediments (at the time of advancement) and shallow clastic sediments (at regressions). These erosion cycles have been associated with bauxite deposition, in which bauxite is deposited within the late Permian. In the interval between Permian and Triassic, the lack of stratigraphy has caused the appearance of bauxite layers on the Ruteh Formation and below the Elika Formation.

\subsection{Chemical composition determination analysis}

To determine the chemical composition of Ghezel Ghiyeh bauxite reserve, XRF (X-ray fluorescence) and ICP-MS (inductively coupled plasma mass spectrometry) analyses were performed, the results are given in Tables 2 and Table 3, respectively. According to Table $2, \mathrm{SiO}_{2}$ with $44.82 \%$ is the predominant compound (impurity) in the sample. The $\mathrm{Fe}_{2} \mathrm{O}_{3}$ grade in the sample (as the target compound to be removed) is equal to $5.14 \%$. It should be noted that the alumina to silica modulus for the studied bauxite sample is 0.73 . This modulus is one of the basics of bauxite quality assessment, and reserves with alumina to silica modulus of more than 10 are considered to be among the best bauxite reserves. As mentioned, following recent changes and advances in technology, the alumina to silica modulus of downstream processes has been reduced to about $1 / 5$, and low to medium-grade bauxite reserves have become economically and practically justified. In the case of the studied bauxite reserve, which is considered a low-grade reserve, its modulus value is expected to increase (to about 2) by performing processing tests.
According to Table 3, the titanium element with a value of $6989.68 \mathrm{ppm}$ has the highest grade amongst the impurities associated with bauxite. Also, the amount of potassium in the sample was measured at $962.47 \mathrm{ppm}$ (see Table 3). Then $\mathrm{Na}, \mathrm{Li}$, and $\mathrm{Ca}$ have the highest values, respectively. According to the table, the amount of light rare earth elements (LREE) of the bauxite sample is equal to $9.42 \mathrm{ppm}$. All heavy rare earth elements (HREE) including Y, Lu, Yb, Tm, Er, Ho, Dy, Tb, Gd, and Eu have values less than $0.5 \mathrm{ppm}$.

\subsection{Mineralogical investigation of studied low-grade bauxite}

The study of polished sections of samples of Ghezel Ghiyeh bauxite ore indicates that the sample is highly heterogeneous in terms of texture and mineralogical composition, so that the rich parts of bauxite and clay minerals are differentiated from iron and titanium compounds. In the laterite parts, hematite is the main phase and less suspicious particles of titanium bearing compounds can be found in it. Clay minerals of the kaolinite type are predominant and small amounts of bauxite minerals, such as diaspora and boehmite are also found. Due to the textural conditions, it seems that the iron compounds, i.e. the laterite part in the form of multiple veins, have intercepted the clay and bauxite parts (see Figure 1). According to the results of $X$-ray diffraction analysis, kaolinite, boehmite, and anatase are the main phases of the sample. Albite can also be seen as a trace phase in the sample. From a constituent mineral standpoint, the sample includes a heterogeneous set of clear and opaque semi-transparent minerals, in which the distribution of metal ores is so heterogeneous that in some parts, the sample lacks opaque compounds. Opaque minerals are found in three size fractions; coarse-grained (up to 0.5 $\mathrm{mm}$ in size), fine-grained and dispersed with dimensions of less than $200 \mu \mathrm{m}$, and concentrated particles in the veins. Among these, iron oxide-hydroxide compounds, such as hematite as well as titanium oxide, with almost equal frequency and a total of about $15 \%$ are visible (see Figure 1). In the samples, very fine to cryptocrystalline sets of clay minerals, bauxite, and iron and titanium 


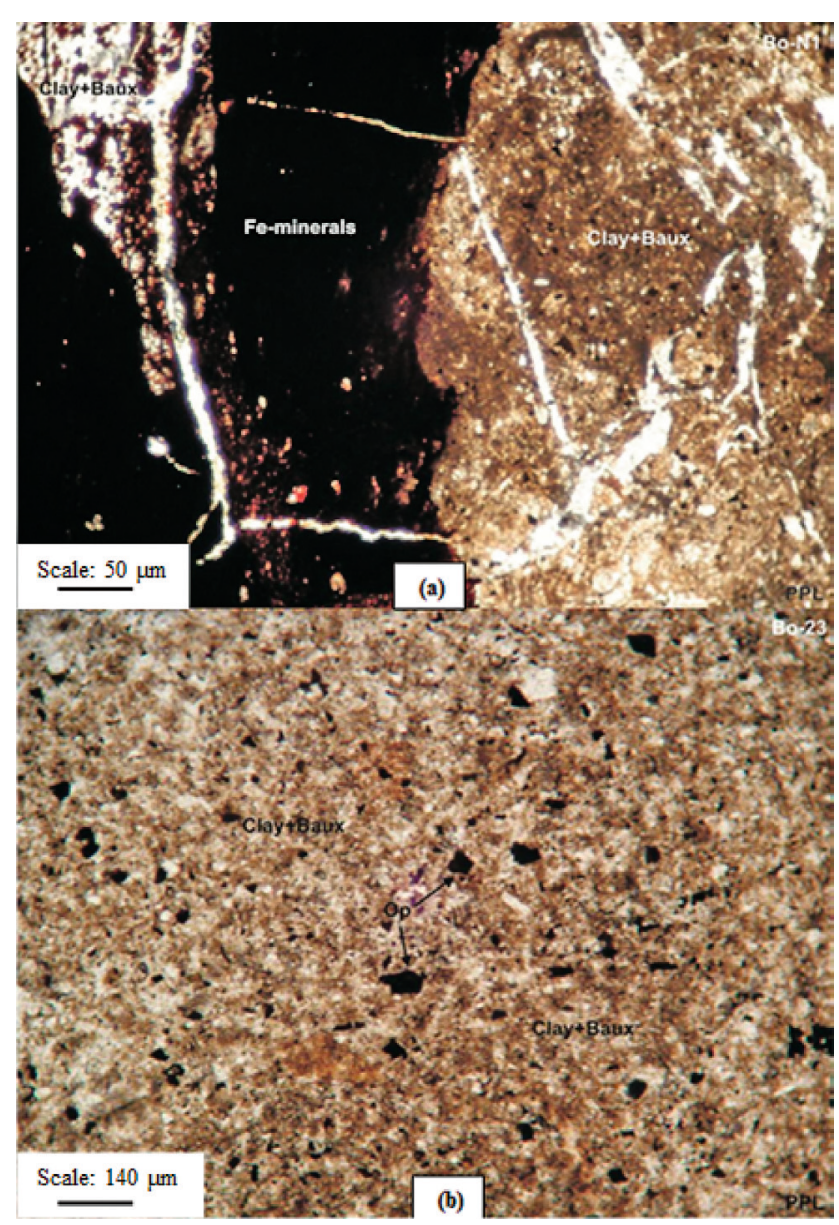

Figure 1: a) Mineralogical texture and structure, type and b) distribution of minerals in microscopic sections of Ghezel Ghiye low-grade bauxite reserve compounds can be seen. Most of the sample is related to clay phases and is mostly kaolinite.

\subsection{Preparation and comminution of bauxite for mineral processing tests}

Iron removal tests, including magnetic, calcination, and leaching, on a bauxite sample from the Ghezel Ghiyeh Mine, are performed after comminution by jaw crushers, roller crushers, and rod mills (during comminution time of 2, 5, and 12 minutes). All comminution devices are in the laboratory scale. The size of the feed of jaw crusher was particles with a size of greater than 5 $\mathrm{mm}$. The output of the jaw and roller crushers was a product with $\mathrm{d}_{80}=1700 \mu \mathrm{m}$. With samples ground in a rod mill (as shown in Figure 2), $\mathrm{d}_{80}$ values of mill output products for comminution in 2,5 , and 12 minutes are 680,490 , and $190 \mu \mathrm{m}$, respectively. The rotation speed of the rod is $95 \mathrm{rpm}$, and its length and diameter are 35 and $15.70 \mathrm{~cm}$, respectively.

According to microscopic studies on bauxite samples after comminution, particles smaller than $4 \mathrm{~mm}$ have a degree of liberation of about $50 \%$. The degree of liberation increased as the particle size became smaller, for instance, the degree of liberation in the $-250 \mu \mathrm{m}$ size fraction increased to more than $90 \%$. White particles (bauxites) are more abundant than other particles, accounting for more than $70 \%$ of the sample at a size of $-250 \mu \mathrm{m}$. Non-bauxite minerals, which are mainly metallic and hematite minerals, are found in two colors, brown ( $20 \%$ of the total particle volume) and leaden. As the size of the fractions becomes finer, particles of color-

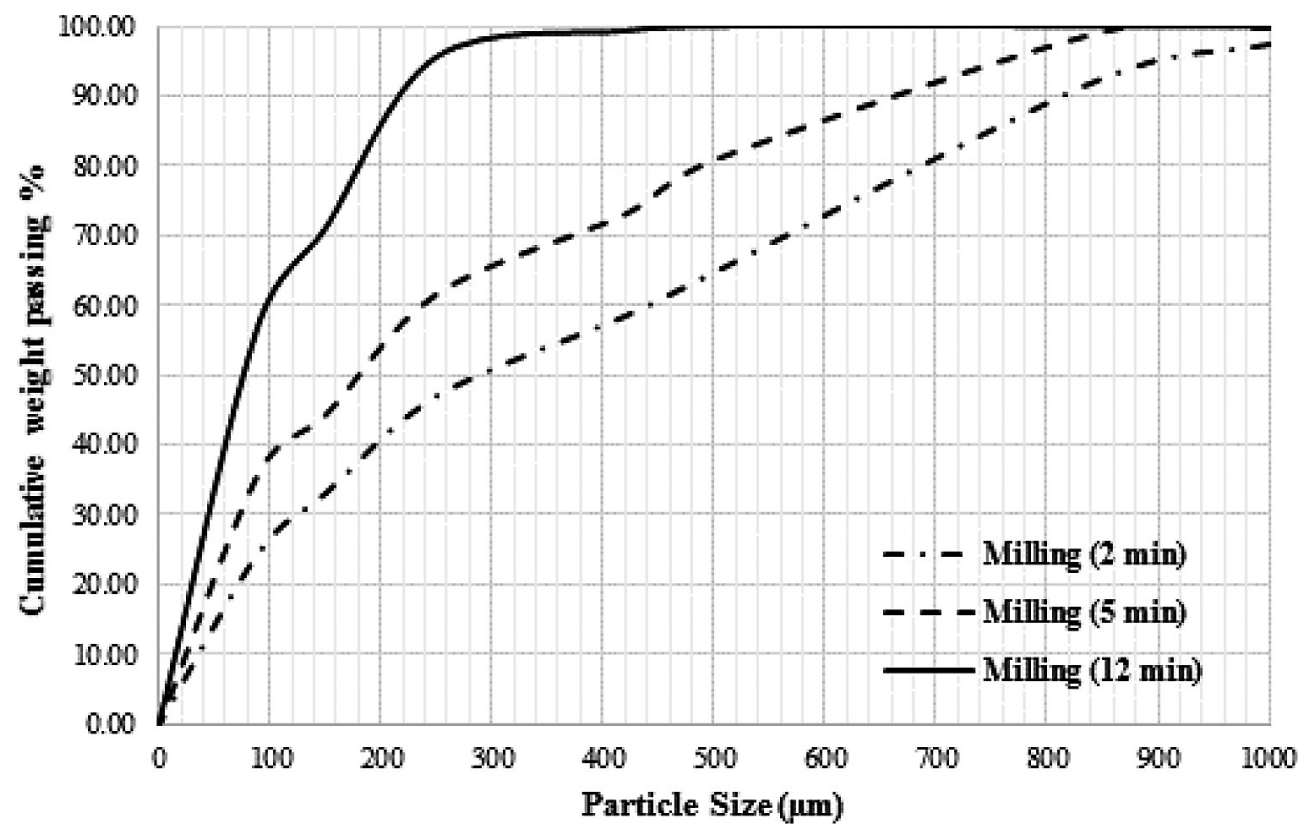

Figure 2: Graphs of bauxite sample size distribution ground by rod mill in the grinding duration of 2, 5, and 12 . 
ed minerals (most likely hematite) are scattered as microscopic particles in the rock texture. Studies of microscopic sections also confirm this, because according to them, iron oxide-hydroxide compounds such as hematite as well as titanium oxide, with almost equal frequency and a total of about $15 \%$ are visible.

\subsection{Mineral processing tests}

Mineral processing tests have been performed in two stages to investigate the possibility of iron removal of low-grade bauxite ores. In the first stage, the effect of magnetic separation, calcination and leaching methods on iron removal were investigated. To investigate the possibility of separating iron from bauxite by magnetic method, a test was performed using a 12000 Gauss dry magnetic separator on the product of the rod mill (This magnetic field selected based on grade Fe and initial test done on sample in 2000 - 12000 gauss). This test did not produce the desired result in iron removal of the bauxite sample (the recovery of $\mathrm{Fe}$ in this test was under $10 \%$ ). During calcination tests, to calcinate the bauxite, a sample from the product of a rod mill with a particle size of less than $75 \mu \mathrm{m}$ was placed in an oven at $900^{\circ} \mathrm{C}$ for one hour. Leaching tests have been performed in two conditions for raw and calcined feed. Also, leaching processes have been repeated for each of the above conditions using hydrochloric acid and sulfuric acid. In each leaching

Table 4: Parameters studied in leaching tests designed by Taguchi method and their values

\begin{tabular}{|l|l|l|l|l|}
\hline $\begin{array}{l}\text { Para- } \\
\text { meter }\end{array}$ & $\begin{array}{l}\text { Particle } \\
\text { Size }(\boldsymbol{\mu m})\end{array}$ & $\begin{array}{l}\text { Acid } \\
\text { Concentra- } \\
\text { tion }(\%)\end{array}$ & $\begin{array}{l}\text { Time } \\
(\text { Min) }\end{array}$ & $\begin{array}{l}\text { Tempera- } \\
\text { ture }\left({ }^{\circ} \mathbf{C}\right)\end{array}$ \\
\hline Levels & $\begin{array}{l}3000- \\
1000-250\end{array}$ & $30-20-15$ & $120-60-20$ & $80-50-25$ \\
\hline
\end{tabular}

\section{Results and Discussion}

\subsection{Iron removal from low-grade bauxite using leaching-calcination method}

Leaching tests using $\mathrm{HCl}$ and $\mathrm{H}_{2} \mathrm{SO}_{4}$ acids were performed on the studied low-grade bauxite samples to reduce the amount of iron content to the permissible stand-

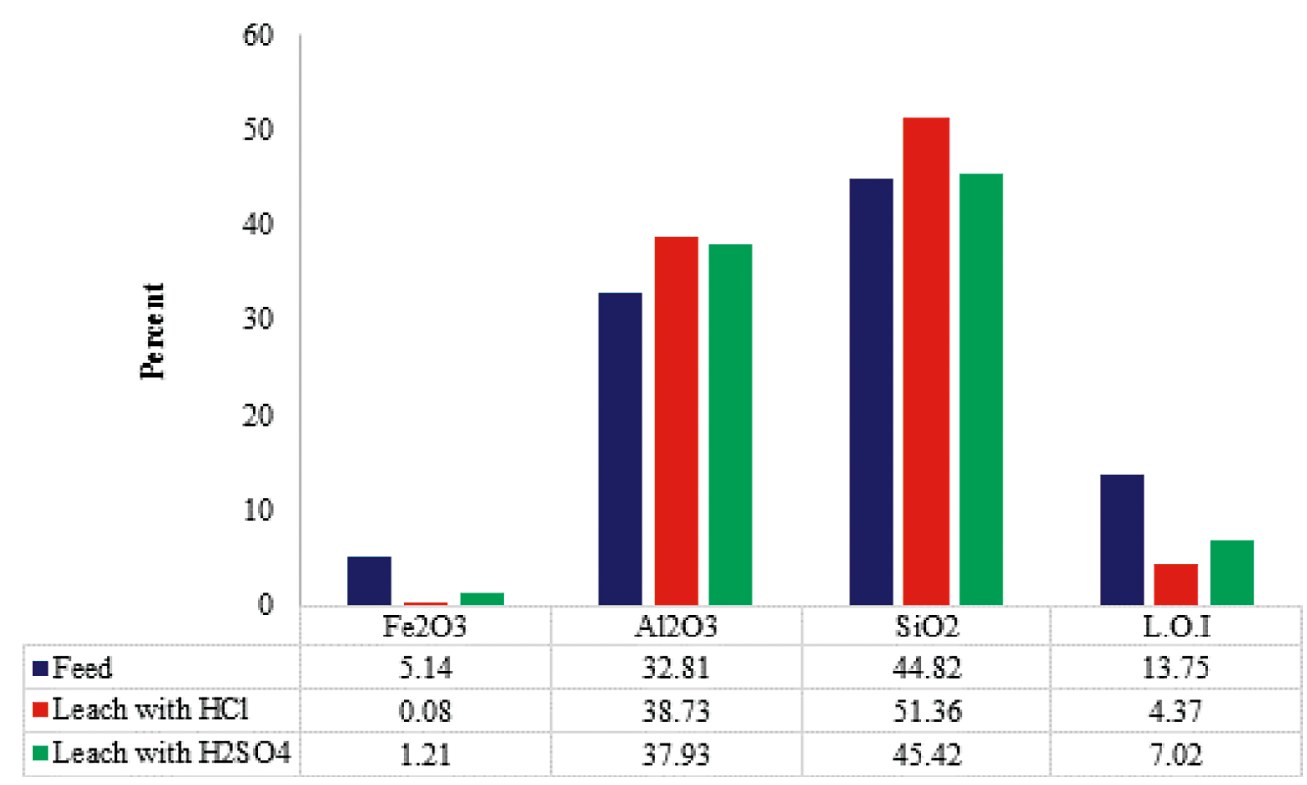

Figure 3: Results for leaching of low-grade bauxite with $\mathrm{HCl}$ and $\mathrm{H}_{2} \mathrm{SO}_{4}$ acids (Raw feed) 
ard of refractory soils $(>2.5 \%)$. These tests were performed under the same conditions, at a concentration of $20 \%$ acid, on a feed with a particle size of $-75 \mu \mathrm{m}$. The $-75 \mu \mathrm{m}$ fraction has been selected based on microscopic studies and the degree of liberation of minerals in this size range. The results of these tests are shown in Figure 3. According to the results, in $\mathrm{HCl}$ leaching, the amount of $\mathrm{Al}_{2} \mathrm{O}_{3}$ in the leaching concentrate increased by about $6 \%$, while the amount of $\mathrm{Fe}_{2} \mathrm{O}_{3}$ reduction was more than $5 \%$. The percentage of volatiles in the leaching concentrate also decreased significantly compared to the feed, but the amount of silica increased (about 7\%). It should be noted that during the bauxite leaching process using $\mathrm{HCl}$, the reactions between acid, $\mathrm{Al}_{2} \mathrm{O}_{3}$, and $\mathrm{Fe}_{2} \mathrm{O}_{3}$ can be seen in Equations 1 and 2 (Roskill, 2016).

$$
\begin{aligned}
& \mathrm{Al}_{2} \mathrm{O}_{3}+6 \mathrm{HCl}=2 \mathrm{AlCl}_{3}+3 \mathrm{H}_{2} \mathrm{O} \\
& \mathrm{Fe}_{2} \mathrm{O}_{3}+6 \mathrm{HCl}=2 \mathrm{FeCl}_{3}+3 \mathrm{H}_{2} \mathrm{O}
\end{aligned}
$$

The use of $\mathrm{H}_{2} \mathrm{SO}_{4}$ has led to a significant reduction in the amount of iron associated with bauxite, but compared to the amount of iron removed by $\mathrm{HCl}$, it can be said that hydrochloric acid had a better result. $\mathrm{Al}_{2} \mathrm{O}_{3}$ levels also increased almost similar to the previous case (increased by $5.22 \%$ ) and LOI also had a decreasing trend and the amount of $\mathrm{SiO}_{2}$ increased by less than $1 \%$. According to the results, the ratio of alumina to silica or its modulus is 0.75 for $\mathrm{HCl}$ leaching concentrate and 0.83 for $\mathrm{H}_{2} \mathrm{SO}_{4}$ leaching concentrate. Therefore, it can be

Table 5: Results of XRF analysis after leaching of calcined bauxite samples with $\mathrm{HCl}$ and $\mathrm{H}_{2} \mathrm{SO}_{4}$

\begin{tabular}{|l|l|l|l|l|l|}
\hline Test & $\begin{array}{l}\mathrm{Al}_{2} \mathbf{O}_{3} \\
\%\end{array}$ & $\begin{array}{l}\mathbf{F e}_{2} \mathbf{O}_{3} \\
\%\end{array}$ & $\begin{array}{l}\mathbf{S i O}_{2} \\
\%\end{array}$ & $\begin{array}{l}\mathbf{L O I} \\
\%\end{array}$ & $\begin{array}{l}\mathbf{A l}_{2} \mathbf{O}_{3} \\
/ \mathbf{S i O}_{2}\end{array}$ \\
\hline Feed & 32.81 & 5.14 & 44.82 & 13.75 & 0.73 \\
\hline $\begin{array}{l}\text { Calcination-leach } \\
(\mathrm{HCl})\end{array}$ & 21.45 & 0.31 & 61.41 & 9.93 & 0.35 \\
\hline $\begin{array}{l}\text { Calcination-leach } \\
\left(\mathrm{H}_{2} \mathrm{SO}_{4}\right)\end{array}$ & 23.59 & 4.98 & 58.86 & 9.63 & 0.40 \\
\hline $\begin{array}{l}\text { Leach (HCl)- } \\
\text { calcination }\end{array}$ & 38.43 & 0.04 & 51.41 & 2.04 & 0.74 \\
\hline
\end{tabular}

stated that leaching with sulfuric acid has a better result in increasing the modulus of alumina to silica.

In supplementary studies, first, low-grade bauxite samples were calcined, and then leaching tests using $\mathrm{HCl}$ and $\mathrm{H}_{2} \mathrm{SO}_{4}$ were performed on them. Table 5 shows the results of the XRF analysis of the products of leaching tests on calcined bauxite feed. According to the results, leaching after calcination, using both acids has led to an increase in the amount of $\mathrm{Al}_{2} \mathrm{O}_{3}$. The reduction in $\mathrm{Fe}_{2} \mathrm{O}_{3}$ content in leaching of calcined feed with $\mathrm{H}_{2} \mathrm{SO}_{4}$ is negligible, but in leaching, by hydrochloric acid, the iron content is significantly reduced (up to $0.31 \%$ ). The increase in $\mathrm{SiO}_{2}$ content in the leaching of calcined feed with sulfuric acid is less than that of hydrochloric acid. In other tests, the effect of calcination after bauxite leaching was investigated. In these tests, the $\mathrm{HCl}$ leaching product was calcined. According to Table 5, calcination after leaching had a very good result in lowering $\mathrm{Fe}_{2} \mathrm{O}_{3}$, and its grade was reduced to $0.04 \%$. Leaching with $\mathrm{HCl}$ and then calcination of its concentrate has also increased the amount of aluminum. Examining the modulus of alumina to silica, for calcination-leaching tests, it is observed that none of the tests performed had a favorable result in increasing this modulus, and even reduced its value.

\subsection{Determination of optimal conditions for leaching of low-grade bauxite by the Taguchi method}

Based on low-grade bauxite leaching tests, it can be concluded that leaching using $\mathrm{HCl}$ has led to the best results in reducing the amount of iron. Therefore, tests have been designed using the Taguchi method to determine the optimal iron removal conditions of bauxite using $\mathrm{HCl}$. In this regard, 9 tests (output of L9 array of the Taguchi method) with three-level changes in four parameters (particle size, acid concentration, leaching time, and temperature) have been performed. According to Table 6, the lowest value for the iron grade is obtained in test No. 3: a temperature of $25^{\circ} \mathrm{C}$, time 120 minutes, $\mathrm{HCl}$ concentration of $30 \%$, and the feed particle size is in the range of $-250 \mu \mathrm{m}$.

Table 6: Conditions and results of leaching tests with $\mathrm{HCl}$ - designed by the Taguchi method

\begin{tabular}{|l|l|l|l|l|l|l|}
\hline No. & Particle Size $(\boldsymbol{\mu m})$ & Acid Concentration $(\mathbf{\%})$ & Time $(\mathbf{m i n})$ & Temperature $\left({ }^{\circ} \mathbf{C}\right)$ & Iron Grade $(\%)$ & $\begin{array}{l}\text { Iron removal } \\
\text { efficiency }(\%)\end{array}$ \\
\hline 1 & 3000 & 15 & 20 & 25 & 6.78 & 7.53 \\
\hline 2 & 1000 & 20 & 60 & 25 & 4.49 & 40.20 \\
\hline 3 & 250 & 30 & 120 & 25 & 0.56 & 92.78 \\
\hline 4 & 3000 & 20 & 20 & 40 & 3.23 & 60.51 \\
\hline 5 & 250 & 30 & 60 & 40 & 6.92 & 11.82 \\
\hline 6 & 1000 & 15 & 120 & 40 & 3.55 & 56.46 \\
\hline 7 & 1000 & 30 & 20 & 60 & 6.51 & 4.26 \\
\hline 8 & 3000 & 15 & 60 & 60 & 3.88 & 43.82 \\
\hline 9 & 250 & 20 & 120 & 60 & 2.49 & 65.03 \\
\hline
\end{tabular}




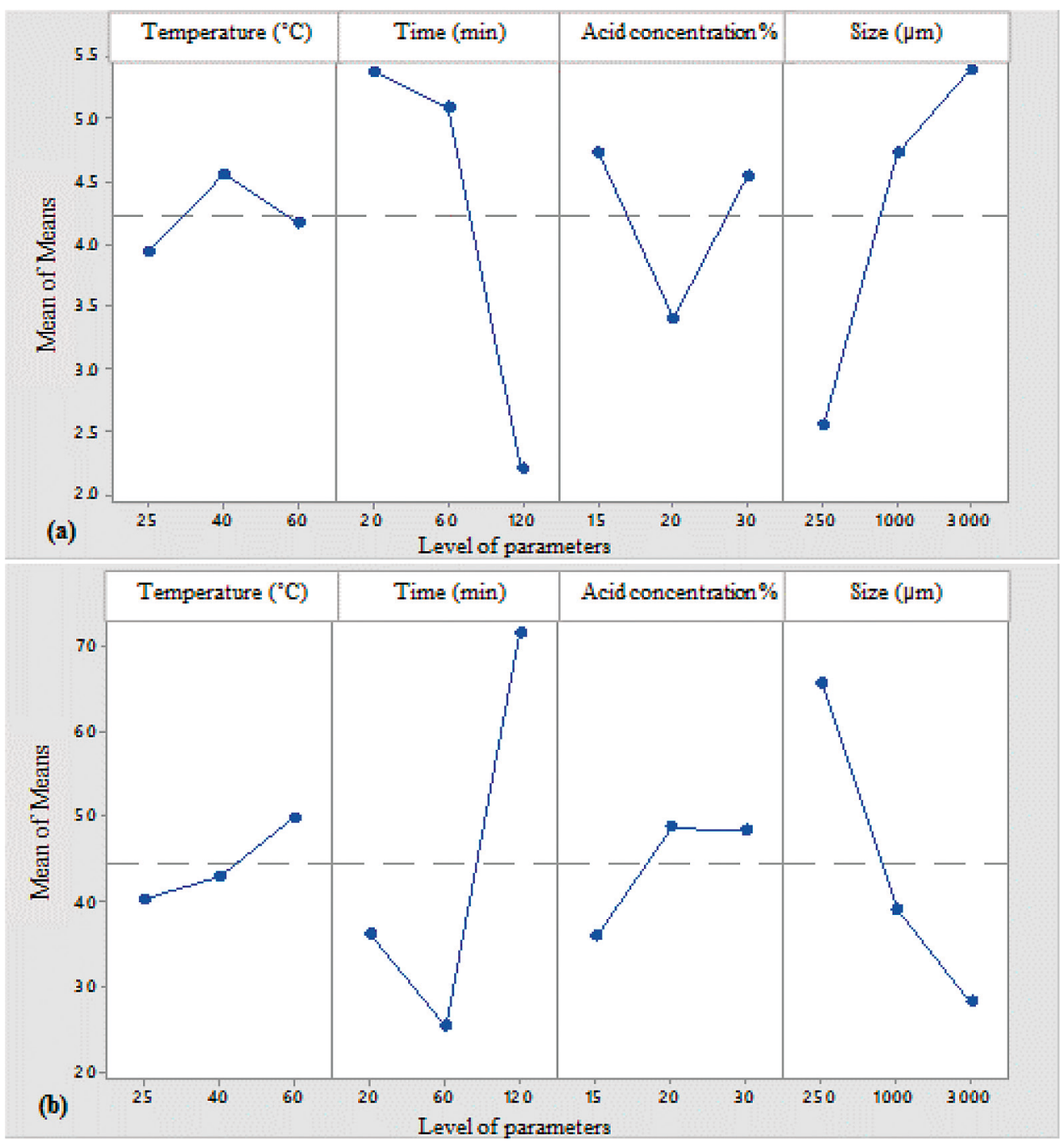

Figure 4: amount of $\mathrm{Fe}_{2} \mathrm{O}_{3}$ a )grade and b) separation efficiency (in leaching with $\mathrm{HCl}^{3}$ acid) in various parameter values

Figure 4 shows the graphs of changes in iron grade and separation efficiency (S.E) of iron removal from bauxite for the different levels of the aforementioned parameters. According to Figure 4, in the case of two parameters of temperature and particle size of the feed, their lowest values (i.e. $25^{\circ} \mathrm{C}$ and 250 microns, respectively) resulted in the lowest grade value of $\mathrm{Fe}_{2} \mathrm{O}_{3}$. Concerning the time parameter, the iron grade has reached the lowest possible level by increasing the test time to 120 minutes. The use of $\mathrm{HCl}$ with a concentration of $20 \%$, also resulted in the best possible reduction in $\mathrm{Fe}_{2} \mathrm{O}_{3}$ content. Based on changes in the separation efficiency of iron removal from bauxite due to changes in test parameters, the best separation conditions for the temperature and time parameters are obtained at $60^{\circ} \mathrm{C}$ and $120 \mathrm{~min}-$ utes of leaching, respectively. Regarding the acid percentage parameter, the best result occurred at $20 \%$ and in terms of feed particle size, the highest separation efficiency was for $250 \mu \mathrm{m}$ particles. Tables 7 and 8 also show ANOVA results for tests. Given the value of $F$ and the significance level, which is greater than 0.05 , it can be concluded that the null hypothesis is confirmed, indicating that there is no difference between the mean of the parameters and the effect is significant.

Figure 5 shows a surface graph of the effect of temperature changes in three values of $25^{\circ} \mathrm{C}, 40^{\circ} \mathrm{C}$, and $60^{\circ} \mathrm{C}$ on iron grade and its separation efficiency. According to Figure 5, it can be said that the best results have been achieved in reducing the iron grade and its removal efficiency at low process temperatures. According to Figure 5b, the maximum separation efficiency is obtained in 120 minutes for the leaching process. Also, the lowest iron content occurred during this period. Figure $\mathbf{5 c}$ is a diagram showing the effect of changes in the concentration of $\mathrm{HCl}$ used in the leaching process at different levels, on the iron content and its separation efficiency. The best results were obtained for reducing $\mathrm{Fe}_{2} \mathrm{O}_{3}$ grade and the highest separation efficiency at $30 \%$ con- 
Table 7: Table ANOVA Effects of leaching parameters on $\mathrm{Fe}_{2} \mathrm{O}_{3}$ grade

\begin{tabular}{|c|c|c|c|c|c|}
\hline \multicolumn{6}{|c|}{ One-way ANOVA: grade versus temperature } \\
\hline Level & $\mathrm{N}$ & Mean & $\mathrm{F}$ & Sig. & St. Dev \\
\hline 25 & 3 & 3.94 & \multirow[t]{3}{*}{0.05} & \multirow[t]{3}{*}{0.951} & 3.15 \\
\hline 40 & 3 & 4.57 & & & 2.04 \\
\hline \multirow[t]{2}{*}{60} & 3 & 4.17 & & & 1.85 \\
\hline & $\mathrm{S}=2.41$ & $\mathrm{R}-\mathrm{Sq}=$ & $.68 \%$ & $\mathrm{R}-\mathrm{Sq}(\mathrm{a}$ & $=0.00 \%$ \\
\hline \multicolumn{6}{|c|}{ One-way ANOVA: grade versus time } \\
\hline Level & $\mathrm{N}$ & Mean & $\mathrm{F}$ & Sig. & St. Dev \\
\hline 20 & 3 & 5.39 & \multirow[t]{3}{*}{0.05} & \multirow[t]{3}{*}{0.108} & 1.89 \\
\hline 60 & 3 & 5.09 & & & 1.60 \\
\hline \multirow[t]{2}{*}{120} & 3 & 2.20 & & & 1.51 \\
\hline & $\mathrm{S}=1.68$ & $\mathrm{R}-\mathrm{Sq}=$ & $2.37 \%$ & $\mathrm{R}-\mathrm{Sq}(\mathrm{a}$ & $=36.49 \%$ \\
\hline \multicolumn{6}{|c|}{ One-way ANOVA: grade versus per acid } \\
\hline Level & $\mathrm{N}$ & Mean & $\mathrm{F}$ & Sig. & St. Dev \\
\hline 15 & 3 & 4.74 & \multirow[t]{3}{*}{0.05} & \multirow[t]{3}{*}{0.760} & 3.15 \\
\hline 20 & 3 & 3.40 & & & 2.04 \\
\hline \multirow[t]{2}{*}{30} & 3 & 3.54 & & & 1.85 \\
\hline & $\mathrm{S}=2.32$ & $\mathrm{R}-\mathrm{Sq}=$ & $.76 \%$ & $\mathrm{R}-\mathrm{Sq}(\mathrm{a}$ & $=0.00 \%$ \\
\hline \multicolumn{6}{|c|}{ One-way ANOVA: grade versus particle size } \\
\hline Level & $\mathrm{N}$ & Mean & $\mathrm{F}$ & Sig. & St. Dev \\
\hline 250 & 3 & 2.56 & \multirow[t]{3}{*}{0.05} & \multirow[t]{3}{*}{0.248} & 1.76 \\
\hline 1000 & 3 & 4.73 & & & 1.32 \\
\hline \multirow[t]{2}{*}{3000} & 3 & 5.40 & & & 2.52 \\
\hline & $\mathrm{S}=1.92$ & $\mathrm{R}-\mathrm{Sq}=$ & $7.20 \%$ & $\mathrm{R}-\mathrm{Sq}(\mathrm{a}$ & $=16.27 \%$ \\
\hline
\end{tabular}

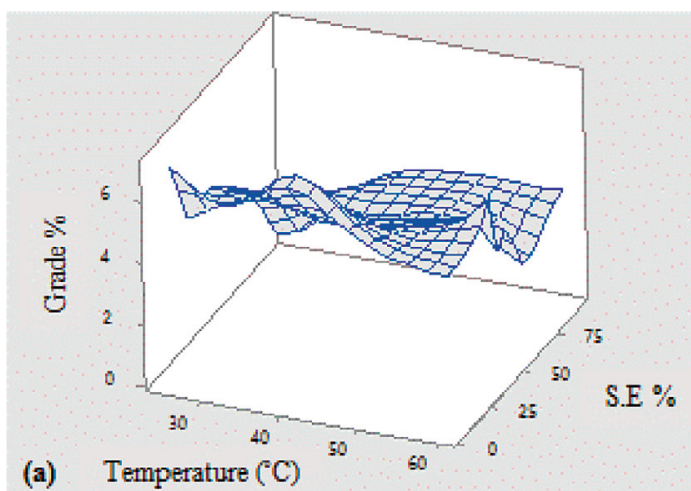

(a) Temperature ('C)

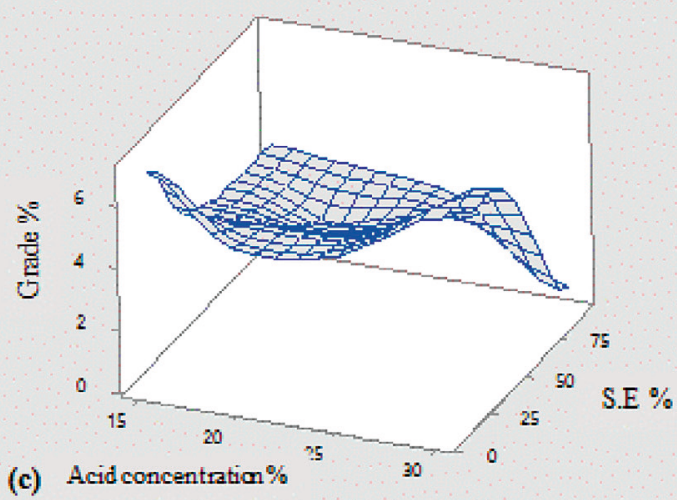

Table 8: Table ANOVA Effects of leaching parameters on separation Iron removal efficiency

\begin{tabular}{|c|c|c|c|c|c|}
\hline \multicolumn{6}{|c|}{ One-way ANOVA: S.E versus temperature } \\
\hline Level & $\mathrm{N}$ & Mean & $\mathrm{F}$ & Sig. & St. Dev \\
\hline 25 & 3 & 40.20 & \multirow[t]{3}{*}{0.07} & \multirow[t]{3}{*}{0.931} & 46.00 \\
\hline 40 & 3 & 42.90 & & & 27.00 \\
\hline \multirow[t]{2}{*}{60} & 3 & 49.79 & & & 13.55 \\
\hline & $\mathrm{S}=31.75$ & $\mathrm{R}-\mathrm{Sq}=$ & $.35 \%$ & $\mathrm{R}-\mathrm{Sq}(\mathrm{ac}$ & $=0.00 \%$ \\
\hline \multicolumn{6}{|c|}{ One-way ANOVA: S.E versus time } \\
\hline Level & $\mathrm{N}$ & Mean & $\mathrm{F}$ & Sig. & St. Dev \\
\hline 20 & 3 & 36.10 & \multirow[t]{3}{*}{0.05} & \multirow[t]{3}{*}{0.082} & 26.70 \\
\hline 60 & 3 & 25.35 & & & 16.56 \\
\hline \multirow[t]{2}{*}{120} & 3 & 71.50 & & & 18.90 \\
\hline & $\mathrm{S}=21.19$ & $\mathrm{R}-\mathrm{Sq}=$ & $6.50 \%$ & $\mathrm{R}-\mathrm{Sq}(\mathrm{ad}$ & $=42.00 \%$ \\
\hline \multicolumn{6}{|c|}{ One-way ANOVA: S.E versus per acid } \\
\hline Level & $\mathrm{N}$ & Mean & $\mathrm{F}$ & Sig. & St. Dev \\
\hline 15 & 3 & 35.90 & \multirow[t]{3}{*}{0.05} & \multirow[t]{3}{*}{0.854} & 25.40 \\
\hline 20 & 3 & 48.70 & & & 24.70 \\
\hline \multirow[t]{2}{*}{30} & 3 & 48.30 & & & 41.10 \\
\hline & $\mathrm{S}=31.30$ & $\mathrm{R}-\mathrm{Sq}=$ & $.11 \%$ & $\mathrm{R}-\mathrm{Sq}(\mathrm{ac}$ & $=0.00 \%$ \\
\hline \multicolumn{6}{|c|}{ One-way ANOVA: S.E versus Size } \\
\hline Level & $\mathrm{N}$ & Mean & $\mathrm{F}$ & Sig. & St. Dev \\
\hline 250 & 3 & 65.70 & 0.05 & 0.262 & 24.90 \\
\hline 1000 & 3 & 39.00 & & & 18.10 \\
\hline \multirow[t]{2}{*}{3000} & 3 & 28.20 & & & 32.20 \\
\hline & $\mathrm{S}=7.25$ & $\mathrm{R}-\mathrm{Sq}=$ & $6.04 \%$ & $\mathrm{R}-\mathrm{Sq}(\mathrm{ad}$ & $=14.72 \%$ \\
\hline
\end{tabular}
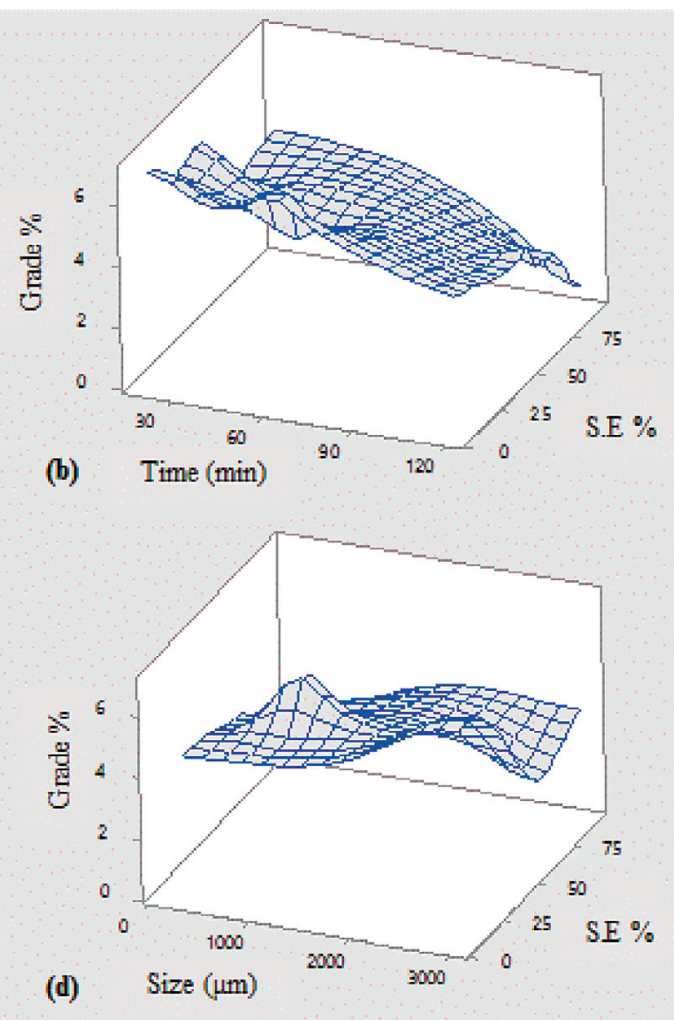

Figure 5: Plot of changes in grade and efficiency of iron separation in relation to changes in levels of leaching process parameters a) temperature, b) time, c) acid concentration, and d) feed particle size 
centration for $\mathrm{HCl}$. The diagram of the effect of changes in feed particle size of the leaching process at different levels of 250,1000 , and $3000 \mu \mathrm{m}$, indicates that with the change in the size range of the feed, the slope of changes in response parameters (grade and S.E.) has been gradual and moderate. However, as a general conclusion, it can be said that in smaller grain size ranges $(-250 \mu \mathrm{m})$ the iron content was lower. Taking into account the effects of different parameter levels, the best efficiency for iron removal has been achieved in the case of $30 \%$ acid use, leaching at a temperature of $25^{\circ} \mathrm{C}$ and 120 minutes for feed with a particle size of -250 microns.

\section{Conclusions}

In this research, an attempt has been made to determine the processing method and its optimal conditions for the iron removal of low-grade bauxite ores and the production of the product for use in refractory soils. By removing iron-bearing minerals from low-grade bauxite ores and producing concentrates per refractory industry standards, in addition to increasing the value-added of the product, it is possible to extract and produce iron compounds such as iron chloride (from leaching solution) as a by-product. According to the results of this study, the leaching of low-grade bauxite ore using hydrochloric acid reduced the amount of iron from 5.14 to $0.08 \%$ and increased the $\mathrm{Al}_{2} \mathrm{O}_{3}$ grade by about $6 \%$. The ratio of alumina to silica or its modulus is 0.75 for $\mathrm{HCl}$ leaching concentrate and 0.83 for $\mathrm{H}_{2} \mathrm{SO}_{4}$ leaching. Therefore, it can be concluded that leaching with sulfuric acid has a better result in increasing the modulus of alumina to silica. Based on the results of the Taguchi design tests, the best removal efficiency for iron in the process of leaching raw feed with a particle size of -250 $\mu \mathrm{m}$ was obtained using $\mathrm{HCl}$ with a concentration of $30 \%$ and a processing time of 120 minutes at $25^{\circ} \mathrm{C}$. The separation efficiency, in this case, is $92.78 \%$.

\section{References}

Cardarelli, F. (2018): Materials handbook. London, Springer, 2254 p.
Deng, B., Li, G., Luo, J., Ye, Q., Liu, M., Peng, Z., and Jiang, T. (2017): Enrichment of $\mathrm{Sc}_{2} \mathrm{O}_{3}$ and $\mathrm{TiO}_{2}$ from bauxite ore residues. Journal of hazardous materials, 331, 71-80.

Deng, B., Li, G., Luo, J., Ye, Q., Liu, M., Rao, M., ... and Zhao, B. (2019): Selectively leaching the iron-removed bauxite residues with phosphoric acid for enrichment of rare earth elements. Separation and Purification Technology, 227, 115714.

Donaldson, D., and Raahauge, B. (2017): Essential Readings in Light Metals, Volume 1, Alumina and Bauxite. Springer, $27 \mathrm{p}$.

Hu, W., Wang, H., Liu, X., Sun, C., and Duan, X. (2016): Restraining sodium volatilization in the ferric bauxite direct reduction system. Minerals, 6, 2, 31 .

Papassiopi, N., Vaxevanidou, K., and Paspaliaris, I. (2010): Effectiveness of iron reducing bacteria for the removal of iron from bauxite ores. Minerals Engineering, 23, 1, 25-31.

Pereira, A.L., Reis, M.A., Ferreira, L.L.H.C., and Nakachima, P.M. (2019): Brazilian refractory grade bauxite: a new alternative to refractories makers and users. Cerâmica, 65, 40-46.

Rai, S., Nimje, M. T., Chaddha, M. J., Modak, S., Rao, K. R., and Agnihotri, A. (2019): Recovery of iron from bauxite residue using advanced separation techniques. Minerals Engineering, 134, 222-231.

Roskill Inf, S. (2016): Bauxite - non-metallurgical: global industry, markets \& outlook to $2021.9^{\text {th }}, 85$ p.

Schacht, C. (2004): Refractories handbook (Vol. 178). CRC Press, 25 p.

Stjernberg, J., Ion, J.C., Antti, M.L., Nordin, L.O., Lindblom, B., and Odén, M. (2012): Extended studies of degradation mechanisms in the refractory lining of a rotary kiln for iron ore pellet production. Journal of the European Ceramic Society, 32(8), 1519-1528.

Yuan, S., Xiao, H., Yu, T., Li, Y., and Gao, P. (2020): Enhanced removal of iron minerals from high-iron bauxite with advanced roasting technology for enrichment of aluminum. Powder Technology, 372, 1-7.

Zhao, A.C., Zhang, T.A., Lü, G.Z., and Dou, Z.H. (2012): Study on the leaching rules of aluminum and ferrum from high iron bauxite by acid leaching at low temperature. Journal of Functional Materials, 43, 105-108.

Zhong, X. (2009): Strategic thoughts on innovative development of Chinese bauxites. Refractories, 43, 4, 241-243. 


\section{SAŽETAK}

\section{Ispiranje željeza iz siromašne rude boksita u cilju njezine uporabe u vatrostalnoj industriji}

Minerali nosioci željeza najvažnije su nečistoće koje se nalaze u rezervama boksita. Željezo ima štetne učinke na primjenu boksita, uključujući korištenje boksita u vatrostalnim tlima. Svrha je ovoga rada istražiti mogućnost uklanjanja željeza iz ruda boksita niske kvalitete radi iskorištavanja u vatrostalnoj industriji. U tu svrhu provedena su ispitivanja izdvajanja željeza na uzorcima boksita s modulom aluminijeva oksida i silicija od o,73. Nakon utvrđivanja odgovarajuće metode za izdvajanje željeza, uključujući magnetsku separaciju, kalcinaciju i luženje (s $\mathrm{H}_{2} \mathrm{SO}$ i $\mathrm{HCl}$ ), određeni su optimalni uvjeti izdvajanja uz upotrebu Taguchijeve metode. Rezultati luženja HCl-om rovne sirovine (nekalcinirane) dali su najbolji rezultat izdvajanja željeza. Tijekom ovoga ispitivanja udio $\mathrm{Fe}_{2} \mathrm{O}_{3}$ smanjio se s 5,14 \% na o,o8 \%, a modul aluminijeva oksida i silicija povećao se na o,75. Kalciniranje koncentrata dobivenoga ovim ispitivanjem dovelo je do povoljnih rezultata u smanjenju nekorisne komponente $\mathrm{Fe}_{2} \mathrm{O}_{3}(0,04 \%)$ i povećanju korisne komponente $\mathrm{Al}_{2} \mathrm{O}_{3}$. Nakon toga u ispitivanjima dizajniranim Taguchijevom metodom određen je utjecaj parametara kao što su vrijeme, temperatura procesa, koncentracija $\mathrm{HCl}$ i veličina zrna sirovine, na uklanjanje željeza iz boksita procesima luženja HCl. Prema dobivenim rezultatima najbolja učinkovitost uklanjanja željeza za veličinu ulaznoga zrna od $250 \mu \mathrm{m}$ postiže se u sljedećim uvjetima: $30 \% \mathrm{HCl}$, temperatura procesa od $25^{\circ} \mathrm{C}$ i vrijeme procesa 120 minuta. U ovome slučaju učinkovitost uklanjanja željeza i sadržaj $\mathrm{Fe}_{2} \mathrm{O}_{3}$ u procesnome koncentratu iznosi $92,78 \%$ odnosno o,56\%.

\section{Ključne riječi:}

boksit, odstranjivanje željeza, ispiranje, Taguchi, vatrostalna industrija

\section{Author's contribution}

Zahra Jalili (MSc student of mineral processing) provided the tests and presentation of the results. Ataallah Bahrami (Associate Professor, Minerals Processing) proposed ideas and advised the research. Masoud Ghadri (MSc of Mining Engineering) proposed ideas and provided the samples. Behzad Nemati Akhgar (Assistant Professor, Minerals Processing) proposed ideas and advised the research. Fatemeh Kazemi (PhD student of mineral processing) performed tests, provided reports and wrote the article. 